\title{
A straightforward approach towards combined $\alpha$-amino and $\alpha$-hydroxy acids based on Passerini reactions
}

\author{
Ameer F. Zahoor, Sarah Thies and Uli Kazmaier*
}

\section{Full Research Paper}

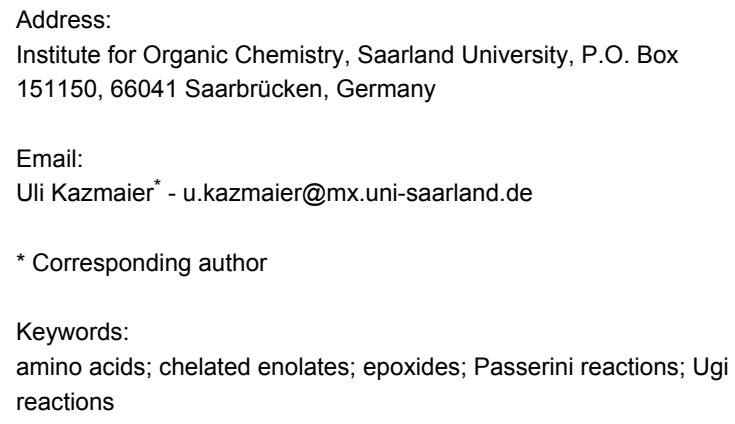

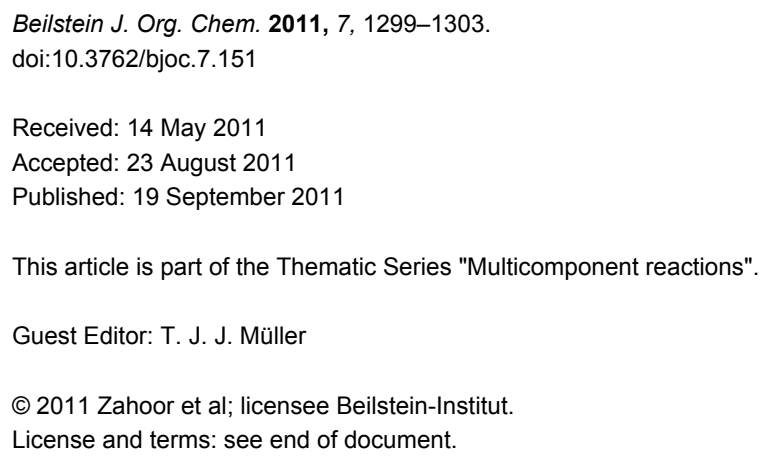

\begin{abstract}
Complex amino acids with an $\alpha$-acyloxycarbonyl functionality in the side chain are easily available through epoxide opening by chelated enolates and subsequent oxidation/Passerini reaction. This protocol works with both, aldehyde and ketone intermediates, as long as the ketones are activated by electron-withdrawing groups. In principle Ugi reactions are also possible, allowing the generation of diamino acid derivatives.
\end{abstract}

\section{Introduction}

Multicomponent reactions (MCR) are a very popular and powerful tool in modern organic synthesis [1-4]. Besides a wide range of heterocycle syntheses [5] and catalytic cross coupling reactions [6], the isonitrile-based MCRs (IMCR) especially have developed exceptionally well during the last few decades $[7,8]$. Based on the pioneering work of Passerini, who observed the first three-component coupling of carbonyls with carboxylic acids and isonitriles in 1921 [9], the so-called Passerini reaction became a powerful tool for the synthesis of acylated $\alpha$-hydroxyacid amides [10]. Later on, in 1961, Ugi and Steinbrückner reported the extension of this protocol by incorporating also a primary amine as a fourth component [11].
Therefore, the Ugi reaction is even more flexible than the Passerini approach, but both reactions together have made the IMCR highly popular in combinatorial chemistry $[7,8]$.

Our group has been involved in amino acid and peptide synthesis for nearly two decades [12,13], and multicomponent reactions are known to play a dominant role $[14,15]$. In particular, the Ugi reaction has so far been used for the construction of exotic peptides [16-19] and cyclopeptides [20,21]. Herein we describe a straightforward protocol towards combined $\alpha$-amino and $\alpha$-hydroxy acids through Passerini reactions. Suitable amino acid precursors with an oxygen functionality in the side 
chain can be obtained by chelated enolate Claisen rearrangement [22,23] or transition metal-catalyzed allylic alkylation of chelated enolates [24] and subsequent oxidative cleavage of the $\gamma-\delta$-unsaturated amino acids obtained.

\section{Results and Discussion}

An alternative approach is based on regioselective ring opening of epoxides, followed by oxidation of the hydroxy amino acid formed. While aryl-substituted epoxides react preferentially at the benzylic position giving rise to the terminal primary alcohols [25], the corresponding alkyl-substituted epoxides provide secondary alcohols $\mathbf{1}$ by nucleophilic attack of the enolate at the sterically least-hindered position [26]. These alcohols can easily be oxidized by Swern-oxidation [27] or with Dess-Martinperiodinane (DMP) [28], giving rise to the required $\gamma$-oxoamino acids 2 (Table 1). In principle both protocols are suitable for oxidation, but in general the yields obtained were better with DMP (82-93\%), while under Swern conditions the yields were in the range of $75 \pm 3 \%$.

With these $\gamma$-oxo- $\alpha$-amino acids 2 in hand, we investigated the Passerini reactions under neat conditions with acetic acid as the (liquid) acidic component and isocyano acetates as the reactive component (Table 2). Interestingly, no reaction was observed

Table 1: Synthesis of $\mathrm{Y}$-oxo-amino acids

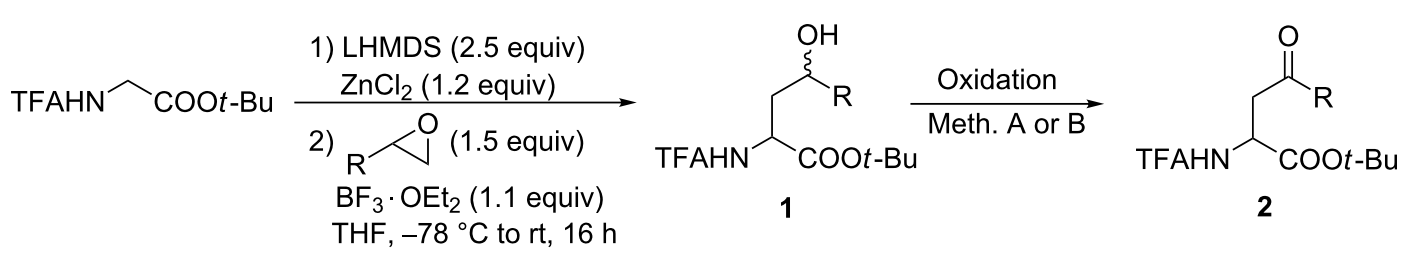

\begin{tabular}{|c|c|c|c|c|c|c|}
\hline \multirow[t]{2}{*}{ Entry } & \multirow[t]{2}{*}{1} & \multirow[t]{2}{*}{$\mathrm{R}$} & \multirow[t]{2}{*}{ Yield (\%) } & \multirow[t]{2}{*}{2} & \multicolumn{2}{|c|}{ Yield (\%) } \\
\hline & & & & & Meth. $A^{a}$ & Meth. $\mathrm{B}^{\mathrm{b}}$ \\
\hline 1 & 1a [26] & $\mathrm{CH}_{3}$ & 92 & $2 a$ & 78 & 91 \\
\hline 2 & 1b [26] & $\mathrm{CH}_{2} \mathrm{Cl}$ & 82 & $2 b$ & 75 & 90 \\
\hline 3 & 1c [26] & $\mathrm{CH}_{2} \mathrm{OC}_{6} \mathrm{H}_{5}$ & 86 & $2 c$ & 76 & 93 \\
\hline 4 & $1 d$ & $\mathrm{CH}_{2} \mathrm{O}-\left(p-\mathrm{Cl}-\mathrm{C}_{6} \mathrm{H}_{4}\right)$ & 88 & $2 d$ & 72 & 82 \\
\hline 5 & $1 e$ & $\mathrm{CH}_{2} \mathrm{O}-\left(\mathrm{o}-\mathrm{NO}_{2}-\mathrm{C}_{6} \mathrm{H}_{4}\right)$ & 84 & $2 e$ & 75 & 87 \\
\hline 6 & $1 f$ & $\mathrm{CH}_{2} \mathrm{O}-\left(p-\mathrm{NO}_{2}-\mathrm{C}_{6} \mathrm{H}_{4}\right)$ & 83 & $2 f$ & 74 & 84 \\
\hline
\end{tabular}

aMethod A: Swern oxidation; bMethod B: DMP oxidation.

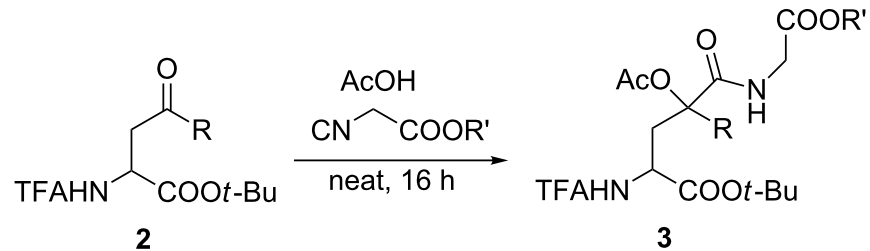

\begin{tabular}{|c|c|c|c|c|c|}
\hline Entry & 2 & $\mathrm{R}$ & $\mathrm{R}^{\prime}$ & 3 & Yield (\%) \\
\hline 1 & $2 a$ & $\mathrm{CH}_{3}$ & $\mathrm{Me}$ & $3 a$ & - \\
\hline 2 & $2 b$ & $\mathrm{CH}_{2} \mathrm{Cl}$ & $\mathrm{Me}$ & $3 b$ & 65 \\
\hline 3 & $2 c$ & $\mathrm{CH}_{2} \mathrm{OC}_{6} \mathrm{H}_{5}$ & $\mathrm{Me}$ & $3 c$ & 57 \\
\hline 4 & $2 d$ & $\mathrm{CH}_{2} \mathrm{O}-\left(p-\mathrm{Cl}-\mathrm{C}_{6} \mathrm{H}_{4}\right)$ & $\mathrm{Me}$ & $3 d$ & 69 \\
\hline 5 & $2 e$ & $\mathrm{CH}_{2} \mathrm{O}-\left(\mathrm{o}-\mathrm{NO}_{2}-\mathrm{C}_{6} \mathrm{H}_{4}\right)$ & $\mathrm{Me}$ & $3 e$ & 62 \\
\hline 6 & $2 f$ & $\mathrm{CH}_{2} \mathrm{O}-\left(p-\mathrm{NO}_{2}-\mathrm{C}_{6} \mathrm{H}_{4}\right)$ & Et & $3 f$ & 69 \\
\hline 7 & $2 d$ & $\mathrm{CH}_{2} \mathrm{O}-\left(p-\mathrm{Cl}-\mathrm{C}_{6} \mathrm{H}_{4}\right)$ & Et & $3 g$ & 68 \\
\hline
\end{tabular}


with the methyl-substituted oxo acid 2a (entry 1); only the starting material was recovered. For this reason, we switched to activated ketones bearing an electron-withdrawing group at the $\alpha$-position. With the chlorinated ketone $2 \mathbf{b}$ the yield was $65 \%$ (entry 2), and similar results were obtained with a range of aryloxy-substituted derivatives $\mathbf{2 c - 2 f}$ (entries 3-7). The new stereogenic center was formed without significant selectivity.

To increase the synthetic potential of this protocol we also applied the Pd-catalyzed opening of a vinyl epoxide with our chelated enolate (Scheme 1) [29]. In this case an amino acid 4 with an allyl alcohol side chain was formed which could be oxidized to the $\alpha, \beta$-unsaturated aldehyde 5 . Although these types of aldehydes are critical candidates in Passerini and Ugi reactions [30], we were interested to see if we could also obtain unsaturated Passerini adducts by this procedure. Our first attempts in $\mathrm{CH}_{3} \mathrm{OH}$ and $\mathrm{CH}_{2} \mathrm{Cl}_{2}$ were unsuccessful. While no reaction was observed in $\mathrm{CH}_{2} \mathrm{Cl}_{2}$, in $\mathrm{CH}_{3} \mathrm{OH}$ the only product (besides starting material) was the unsaturated acetal resulting from a nucleophilic attack of the solvent on the aldehyde group. Therefore, we decided to run the reaction also under neat conditions as reported for the $\gamma$-oxo-amino acids. With acetic acid as the acidic component the yield of $\mathbf{6 a}$ was comparable to the previous examples. In principle, other acids such as benzoic acid or Cbz-protected glycine can be used as well. The lower yield obtained in these cases probably results from stirring problems under these solvent-free conditions.

To circumvent the problems caused by the $\alpha, \beta$-unsaturated aldehyde, we hydrogenated 4 before oxidation to obtain the saturated aldehyde 7 . And indeed, under our optimized reaction conditions the addition product 8 could be obtained in $80 \%$

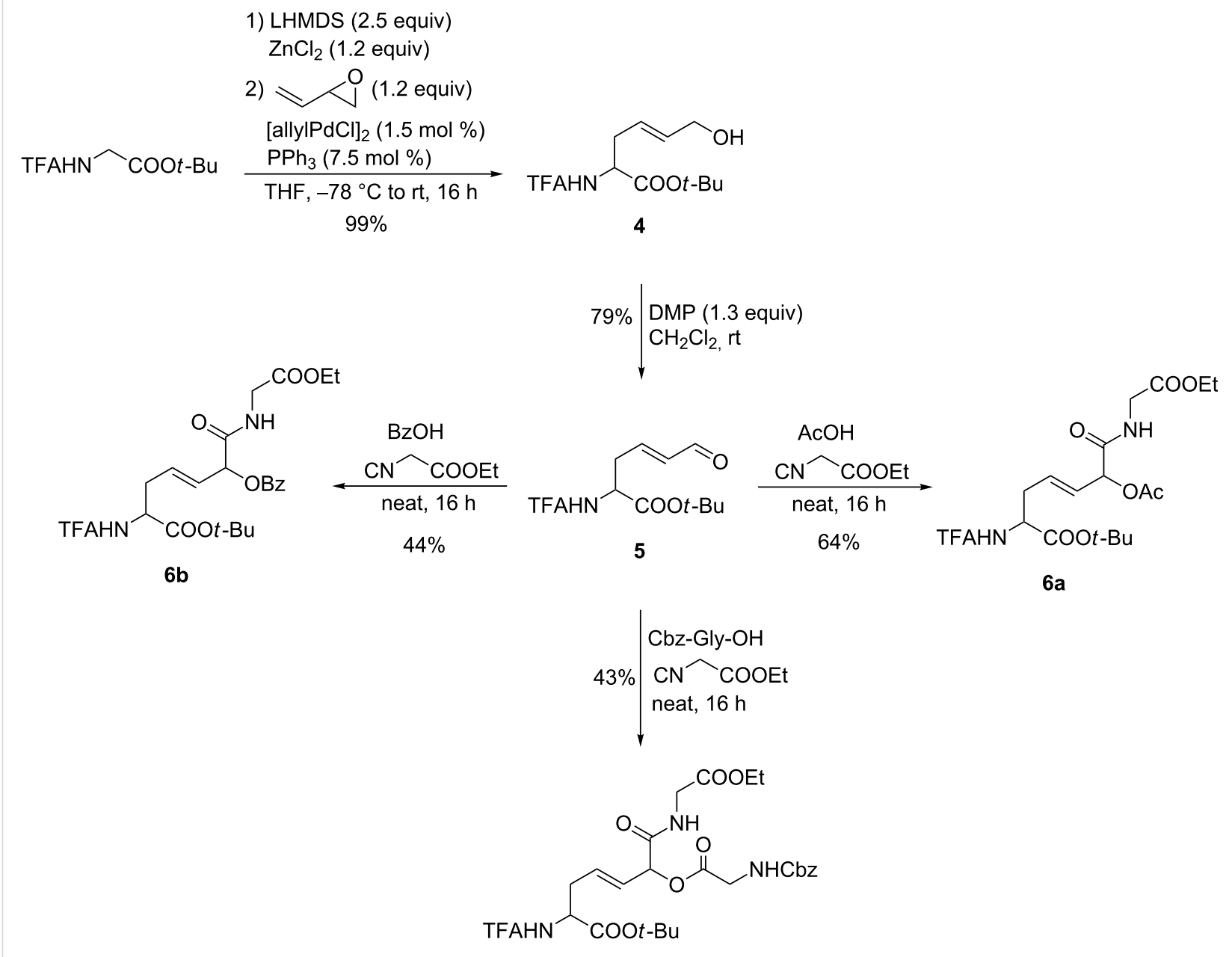

6c 
yield (Scheme 2). In principle, Ugi reactions are also possible, as illustrated with the formation of $\mathbf{9}$, although the yield was significantly lower in this case and the products are formed as a 1:1 diastereomeric mixture.



Scheme 2: Passerini and Ugi reaction of saturated aldehyde 7.

\section{Conclusion}

In conclusion, we showed that the ring opening of epoxides, either directly or Pd-catalyzed, with chelated enolates combined with Passerini reactions is a suitable tool for the synthesis of highly functionalized $\alpha$-hydroxy and $\alpha$-amino acid derivatives. These new compounds are interesting building blocks for peptide-derived drugs. Attempts to improve the yields and to evaluate the scope and limitations are currently underway.

\section{Supporting Information}

Supporting Information features detailed experimental procedures, NMR as well as analytical data of all compounds.

\section{Supporting Information File 1}

Experimental section.

[http://www.beilstein-journals.org/bjoc/content/ supplementary/1860-5397-7-151-S1.pdf]

\section{Acknowledgements}

This work was supported by the Deutsche Forschungsgemeinschaft. A. F. Zahoor thanks the DAAD and HEC (Pakistan) for a PhD fellowship.

\section{References}

1. Ramón, D. J.; Yus, M. Angew. Chem. 2005, 117, 1628-1661. doi:10.1002/ange. 200460548

Angew. Chem., Int. Ed. 2005, 44, 1602-1634. doi:10.1002/anie.200460548

2. Zhu, J.; Bienaymé, H., Eds. Multicomponent reactions; Wiley: Weinheim, Germany, 2005.

3. Dolle, R. E.; Le Bourdonnec, B.; Morales, G. A.; Moriarty, K. J. Salvino, J. M. J. Comb. Chem. 2006, 8, 597-635. doi:10.1021/cc060095m

4. Touré, B. B.; Hall, D. G. Chem. Rev. 2009, 109, 4439-4486. doi:10.1021/cr800296p

5. Isambert, N.; Lavilla, R. Chem.-Eur. J. 2008, 14, 8444-8454. doi:10.1002/chem.200800473

6. Candeias, N. R.; Montalbano, F.; Cal, P. M. S. D.; Gois, P. M. P. Chem. Rev. 2010, 110, 6169-6193. doi:10.1021/cr100108k

7. Dömling, A. Chem. Rev. 2006, 106, 17-89. doi:10.1021/cr0505728

8. El Kaim, L.; Grimaud, L. Tetrahedron 2009, 65, 2153-2171. doi:10.1016/j.tet.2008.12.002

9. Passerini, M. Gazz. Chim. Ital. 1921, 51-2, 126-129.

10. Banfi, L.; Riva, R. The Passerini Reaction. Organic Reactions; Wiley: New Jersey, 2005; Vol. 65, pp 1-140. doi:10.1002/0471264180.or065.01

11. Ugi, I.; Steinbrückner, C. Chem. Ber. 1961, 94, 734-742. doi:10.1002/cber.19610940323

12. Kazmaier, U.; Maier, S.; Zumpe, F. L. Synlett 2000, 11, 1523-1535. doi:10.1055/s-2000-7904

13. Deska, J.; Kazmaier, U. Curr. Org. Chem. 2008, 12, 355-385. doi:10.2174/138527208783743697

14. Schmidt, C.; Kazmaier, U. Org. Biomol. Chem. 2008, 6, 4643-4648. doi:10.1039/b811382c

15. Kazmaier, U.; Schmidt, C. Synlett 2009, 1136-1140. doi:10.1055/s-0028-1088150

16. Kazmaier, U.; Hebach, C. Synlett 2003, 1591-1594. doi:10.1055/s-2003-40987

17. Pick, R.; Bauer, M.; Kazmaier, U.; Hebach, C. Synlett 2005, 5, 757-760. doi:10.1055/s-2005-863722

18. Kazmaier, U.; Ackermann, S. Org. Biomol. Chem. 2005, 3, 3184-3187. doi:10.1039/b507028g

19. Kazmaier, U.; Persch, A. Org. Biomol. Chem. 2010, 8, 5442-5447. doi:10.1039/c0ob00453g

20. Hebach, C.; Kazmaier, U. J. Chem. Soc., Chem. Commun. 2003, 596-597. doi:10.1039/b210952b

21. Kazmaier, U.; Hebach, C.; Watzke, A.; Maier, S.; Mues, H.; Huch, V. Org. Biomol. Chem. 2005, 3, 136-145. doi:10.1039/b411228h

22. Kazmaier, U.; Maier, S. Tetrahedron 1996, 52, 941-954. doi:10.1016/0040-4020(95)00946-9

23. Krebs, A.; Kazmaier, U. Tetrahedron Lett. 1996, 37, 7945-7946. doi:10.1016/0040-4039(96)01764-9

24. Kazmaier, U. Curr. Org. Chem. 2003, 7, 317-328. doi:10.2174/1385272033372888

25. Zahoor, A. F.; Kazmaier, U. Synthesis 2011, 7, 1059-1066. doi:10.1055/s-0030-1258460

26. Kazmaier, U.; Zahoor, A. F. ARKIVOC 2011, IV, 6-16.

27. Mancuso, A. J.; Huang, S.-L.; Swern, D. J. Org. Chem. 1978, 43 , 2480-2482. doi:10.1021/jo00406a041

28. Dess, D. B.; Martin, J. C. J. Org. Chem. 1983, 48, 4155-4156. doi:10.1021/jo00170a070

29. Thies, S.; Kazmaier, U. Synlett 2010, 1, 137-141. doi:10.1055/s-0029-1218536 
30. Baker, R. H.; Schlesinger, A. H. J. Am. Chem. Soc. 1945, 67, 1499-1500. doi:10.1021/ja01225a027

\section{License and Terms}

This is an Open Access article under the terms of the Creative Commons Attribution License

(http://creativecommons.org/licenses/by/2.0), which permits unrestricted use, distribution, and reproduction in any medium, provided the original work is properly cited.

The license is subject to the Beilstein Journal of Organic Chemistry terms and conditions:

(http://www.beilstein-journals.org/bjoc)

The definitive version of this article is the electronic one which can be found at:

doi:10.3762/bjoc.7.151 